\title{
CSR PROGRAM AXIATA GROUP IN Promoting Human Development
}

\author{
Ardha Prisia* \\ Universitas Airlangga Surabaya \\ Jl. Airlangga No.4 - 6, Airlangga, Gubeng, Surabaya, Jawa Timur \\ 60115
}

https://ijireview.com/ijir

e-ISSN:

p-ISSN:

IJIR REVIEW 1 (1) (2020): 37-43

Received: 25 July 2020; Accepted: 1 August 2020; Published

online: 30 September 2020

\section{Abstract}

DOI:

Corporate Social Responsibility is a very broad yet complex concept, It is a commitment from corporations or businesses to consider the social and environmental impact from their business activities, aims to give a positive impact to the society and the company, either in the aspects of economics, social, environment, or others. This paper discussed the implementation of Axiata Group's CSR Program and being analyzed by the human development theory, using three indicators that are being used in Human Development Index (HDI), namely Education, Health, and Economics. The research is using qualitative methodology to gain the data and pieces of information that are needed and the research found that Axiata Group's CSR program is considered a successful one. However, the research found that their program is mainly circled in Education and Economic Field. But no regard for the public health field. Therefore, the companies need to plan the CSR program to improve public health, especially during this Covid-19 pandemic.

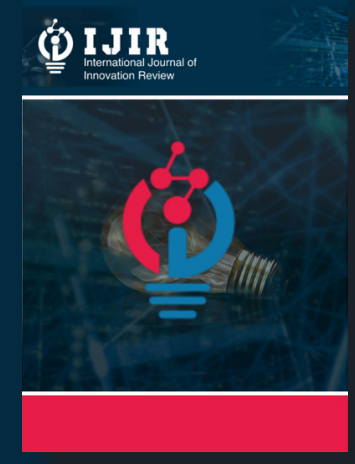

\section{INTRODUCTION}

In running a business, a company sometimes carries out business activities that can cause impacts and disruptions to society, both in environmental and social impacts, either directly or indirectly. To overcome the impact caused by the company's business activities, it is necessary to implement corporate social responsibility or what is commonly known as corporate social responsibility (CSR), as a way to balance the impacts that have been caused by business activities.

CSR is a very familiar concept known in the business and business world, both in the public sector and private(Wardiyanto, 2012, p. 77). Because CSR is one of several parts of Corporate Responsibility or corporate responsibility, so whether there are rules or not, the business sector will continue to carry out CSR as a social responsibility activity to the community (Budiarti \& Raharjo, 2014).

If defined, the concept of CSR is quite broad and complex. Where CSR itself has a very wide and varied scope. Broadly speaking, CSR can be defined as the relationship between a business world and business or the private sector with the government and local communities or the public sector. As well as the company's relationship with stakeholders or stakeholders (Crowther \& Aras, 2008). The definition of CSR is also stated by Solihin (2009). He divides the notion of CSR into three (3) things, namely; The first is CSR as a company>s commitment to improving peopless welfare 
through discretionary business practices or the contribution of company resources. Second, CSR is a way for companies to achieve commercial success by respecting ethical values and respecting society and the environment. The third is CSR as a company>s desire to consider social and environmental impacts in the decision-making process as evidence of the companyss accountability for its decisions and business activities.

Wibisono (2007) states that CSR is a form of business or company commitment to make ethical contributions to the economic development of society. Kurniasari (2015) also explains that CSR is a way for companies or the business world to form a balance and integration of economic, environmental, and social issues. From the definitions of CSR that have been mentioned above, it can be concluded that CSR is a company's relationship and commitment with its stakeholders. This commitment is based on considerations of social and environmental impacts in the decision-making process and business activities of the company. To improve the welfare of the people around it.

The existence of CSR itself was started in 1953. At that time, CSR was only oriented to philanthropic activities. In its development, CSR was divided into three periods, namely the 1950-1960s, 19701980 s, and 1990s to date. CSR concept is used today refers to the theories of John Elkington in 1998 entitled "Cannibals with Forks: The Triple Bottom Line of21st Century Business (Mondza,2017). In the book, it is explained that there are three (3) basic pillars for companies or the business world to carry out CSR programs, namely, programs that are made and implemented must refer to the triple bottom line: People, Profit, Planet.

In Indonesia, the development of CSR has been around since the 1990s. At that time, the business world and companies have implemented activities that have a similar principle base to the concept of CSR such as Corporate Social Activity (CSA), corporate giving and charity, corporate social relations, and others (Mondza, 2017). However, discussions on the concept and implementation of CSR began to be noticed and debated in 2005. CSR was scheduled to become a national legislation program and included in the Limited Liability Company Bill. In 2007, officially CSR regulations and discussion of CSR in Indonesia were included in several laws and regulations such as; Article 15 and Article 34 of Law Number 25 of 2007 concerning Investment, Article 74 of Law Number 40 of 2007 concerning Limited Liability Companies, Law Number 4 of 1982 and Law Number 23 of 1997 concerning Environmental Management (Harahap , 2010).

It is important to discuss and develop CSR itself. CSR plays a role in the social and economic environment. CSR is also a business commitment to contribute to economic development, improve public services, and improve welfare, quality of life, and the competence of the community together (Astri, 2012). CSR has several benefits for society. CSR can be used to improve the quality of human resources, institutions, savings, consumption, and investment in citizen households. Likewise with Wibisono (2007), who explained that the benefits of CSR are divided into three; namely benefits for individual employees, where CSR is used as an alternative learning tool in running a business or business. Benefits for program recipients where CSR can provide new skills and abilities that the community had not previously had. As well as benefits for the company, CSR can be used to increase the capacity and capability of employees.

Besides, the implementation of CSR can also contribute to financial income. One of them can be seen in Indonesia. In Indonesia, the quantity and quality of implementing CSR programs continue to increase (Tanudjaja, 2006). In 2001, it was recorded that CSR funds reached Rp. 115 billion from 180 companies and allocated in 279 CSR programs, or social activities. The benefits of CSR can also be felt by the company as a program provider. CSR can be used as a medium to build a company's image and brand image as well as public trust in the company (Handayani, 2020).

One company that is very interesting to discuss its CSR program is the Axiata Group company, which is a multinational corporation $(M N C)$ based in Malaysia. The company is a company engaged in providing telecommunications providers and has become one of the largest telecommunications companies in Asia. XL focuses on Southeast Asia and South Asia, with several subsidiary companies, such as Celcom Axiata Bhd in Malaysia, XL Axiata in Indonesia, Ncell in Nepal, Dialog in Sri Lanka, Smart in Cambodia, and Robi in Bangladesh and others.

To analyze the CSR program of the Axiata Group, a sample of Axiata Group subsidiary companies can be used. In this study, the authors limit the two subsidiary companies, namely Celcom Axiata Berhad, which is the main branch of the Axiata Group subsidiary. Both are based in Malaysia. Besides, researchers also took samples from a subsidiary of the Axiata Group based in Indonesia, PT. XL Axiata.

\section{MeThoD}

This research uses qualitative-descriptive research methods. This qualitative-descriptive research intended to understand a phenomenon and explain this phenomenon (Sugiyono, 2008), in this case, the CSR program of the Axiata Group, in detail. In conducting research and writing articles, the author uses several data and information 
collection techniques, namely using interviews, observation, and documentation or literature study techniques. To obtain the data and information needed to explain the CSR program from Celcom Axiata Berhad, researchers used direct interview techniques to one of the Celcom Axiata Berhad parties. Meanwhile, to obtain data and information about the CSR program from PT. XL Axiata is done through observation and documentation through literature reviews such as previous research, journal articles, and news as well as annual reports from companies. The two branches of the company were chosen because they both have a fairly large and dominant contribution in the provision of telecommunications services in their respective countries. Besides, the two countries owned, namely Indonesia and Malaysia, are considered to be the Axiata Group ss biggest markets. The two countries also have the same characteristics, both in terms of consumer behavior, language and others.

\section{RESULTS AND DISCUSSION}

Engaged in the provision of telecommunications services, Axiata Group is a multinational company or multinational company (MNC) based in Malaysia. Axiata itself can be said to be one of the largest telecommunications service providers in Asia. where the company already has 11 subsidiary business branches spread across several countries in Southeast Asia and South Asia and has around 150 million customers.

The Axiata Group aims to advance Asia by promoting digital inclusion and community empowerment. Axiata Group has four main values of business activities, namely, performance and performance, cooperation, people and planet, and society. To form these main values, the Axiata group has two main strategies, namely through trust stakeholder, which is achieved using organizational management, and through sustainability. Axiata Group tries to contribute to the country's development. They claim that they have contributed around USD 8.4 billion to the GDP of 6 countries where Axiata Group operates, support the climate change agenda (support the GSMA's Carbon Emissions by 2050 initiative), and support the digital economy in the local economic sector (MSMEs).

Axiata Group divides its CSR programs as a whole Group as well as Individual OpCos. Both focus on empowerment and improving the quality of life. Overall, the Axiata Group can be said to have had a sizeable impact on the countries where its subsidiaries operate. Most of these impacts come from Axiata Group's CSR programs in promoting and supporting sustainability. Besides, Axiata Group has also provided about 600,000 jobs in regional scope. In the social sphere, Axiata Group has supported MSMEs by providing digital financial services, helping approximately more than 630,000 workers in agriculture modernize their jobs. As well as empowering more than two million women by using digital education, employment, and financial services, as well as providing assistance to disasterstricken areas, and others.

The Axiata Group has also subsidized 4,000 families in the provision of electrical energy services, donating around RM 2 million to the MARA Foundation. Besides, it supports the education of more than 100,000 students spread across Malaysia, Indonesia, and Cambodia through the Axiata Young Talent program, supports digital learning of more than 800,000 students, and provides scholarships in the field of education. Besides, to minimize the carbon footprint and waste created by the company, Axiata Group has had excellent environmental management until 2019 by using more than 1,708 solar power plants, reducing carbon emissions using bamboo towers, and reducing around 54\% of emissions since 2013.

\section{A. Celcom Axiata Berhad}

Founded in 1988, Celcom, which is a member of Axiata Group, is the first mobile operator in Malaysia. To date, Celcom has served around 98\% of Malaysia with 4G network services covering around $76 \%$ of the population in Malaysia. Besides, Celcom also has around 9.7 million subscribers throughout Malaysia. To provide its services, Celcom believes that talent, innovation, good operations, and digitalization will be the keys to creating a good customer experience.

In connection with the company's CSR program, Celcom focuses on activities aimed at empowering the community and improving the quality of life of the community. Where most of the programs owned by Celcom cover certain fields such as education, environmental protection, and health, and sports. Some examples of Celkom's CSR programs are:

\section{Tuisyen Mara - Celcom Program}

Tuisyen Mara-Celcom is an initiative initiated by Celcom together with YPM to provide free education funds for 2,900 SPM candidates (students) who come from low-income families, especially those from remote areas. Besides, this program also provides direct guidance to students through specialist tutors and mentors from the foundation.

\section{KPM-Celcom Siswapreneur Program}

KPM-Celcom SiswaPreneur Program is an annual Celcom program initiated in 2016. In running this program, Celcom collaborates with the Malaysian Ministry of Education. This 
StudentPreneur Program aims to cultivate the soul, mind, and talents of an entrepreneur or entrepreneur among college students. Apart from providing training on the entrepreneurial spirit, this program also provides tools for students to demonstrate entrepreneurial characteristics and spirit. Until 2018, 35 higher education institutions collaborated with Celcom to run this program.

\section{DESA MALL}

DesaMall is an initiative of Celcom Axiata Berhad in conjunction with The Rural and Regional Ministry in the rural area transformation program. This program is one of the governmentss efforts to provide online business benefits to remote area communities, especially(Indigenous PeopleIndigenous People) or indigenous peoples.

Similar to SiswaMall, DesaMall provides a platform for Malaysian indigenous peoples to sell the products they make and sell digitally. Besides, there is also training on the digital business cycle for entrepreneurs, the impact of this program is that around 150 entrepreneurs who come from rural areas experience an increase in income by $30 \%$.

In addition to the programs mentioned above, Celcom at the time of the Covid-19 pandemic also had several programs to help the community in suppressing the curve of the spread of Covid-19 in Malaysia, one of which was Celcom distributing SIM cards containing internet data quota for free to support. School and work From Home.

\section{B. PT. XL Axiata, Indonesia}

PT. XL axiata Indonesia is one of the wellknown companies in Indonesia which is engaged in the provision and operation of telecommunications services and/or telecommunications networks and/or multimedia. PT. XL was first established in 1989 and officially started commercial operations in 1996 with a focus on the Jakarta, Bandung, and Surabaya areas. In its development, PT. XL axiata was transformed into a subsidiary of the TM Group (Telekom Malaysia) in 2005 and in 2008 officially became part of the Axiata Group Berhad (TM International Berhad) together with Celcom from Malaysia and other axiata groups spread throughout Southeast Asia. This company continues to grow until now PT. XL axiata received the title as one of the leading telecommunication and / or multimedia network providers in Indonesia.

Regarding the CSR program owned by PT. XL Axiata (XL), in carrying out its social responsibility, XL has several programs that it carries out, these programs are implemented based on four social pillars which include technology development for community welfare (Process Excellence), developing business and good governance (Profits and Professionalism), concern for the environment
(Planet and Environment), and community development and youth talent development (People and Community Development). Besides, before carrying out CSR, XL also conducts surveys and research so that the programs implemented can match the needs of the community.

One of the programs in the social community sector is the Laut Nusantara program. This program is an application intended for sailors and fishermen. This application can help them determine the location of the fish with sufficient accuracy so that fishermen and sailors can get maximum results. Until now, Laut Nusantara already has 8,433 active users and reaches 25,000 downloads.

Another program in the social community sector is the BERBAGI (Together Building the Country) program. This program is a program that enables PT. XL Axiata to feel something different. In this SHARE program, employees can contribute to building the country individually through various social activities.

Next up is the XL Future Leaders (XLFL) program. XLFL is the main program in the company's real support of the government's commitment to realizing good education services for all Indonesian people by developing Human Resources owned by Indonesia. The program, XL Future Leaders which has been running since 2012, is intended as a medium to develop the capacity of Indonesiass young generation and prepare them as leaders who can compete globally in the future. This program runs by providing scholarship funds to college students in pursuing their education. Not only providing financial assistance, but the program $X L$ Future Leaders also assists in capacity building and soft skills for Indonesia>s young generation by providing training, talk shows, seminars, holding competitions, Forum Group Discussions (FGD), and others, with a target of printing 10,000 prospective leaders within 10 years.

The next program is the XL Axiata Youth Leadership Camp (XLYC). XLFC is one of XL's CSR programs which aims to build and train young soft skills prospective leaders . As explained by the World Economic Forum, ten important abilities can support the era of industrial revolution 4.0, such as Creativity, Problem Solving, Critical Thinking, Collaboration, and others. Another program is to $L E A R N$, a digital platform that contains materials and curricula in the XLFL program for self-development. Kemduan Quota Donation Movement (GDK), is a CSR program from XL in the form of raising funds from customers and the public to donate their data package quotas to be distributed to those in need. Last is Sisternet. Sisternet is a CSR program from XL that aims to empower Indonesian women to be more developed and to improve the overall standard of human living.

In the field of environmental management, 
PT. XL Axiata is determined to protect and conserve the environment through energy savings, technological innovation, and other initiatives, such as occupational health and safety as well as community and customer satisfaction. In addition to the above-mentioned CSR programs, XL also provides CSR in the form of assistance during the Covid-19 pandemic. XL tries to help the government and the public in dealing with the Covid-19 pandemic by providing donations of Personal Protective Equipment (PPE), credit, and giving free quota to the community (Wardani, 2020).

\section{Policy Analysis And Suggestions}

From the data and information regarding the CSR program owned by Axiata Group, which is seen from the perspective of the integration of the whole group and the perspective of OpCos (Operation Individual) Celcom Axiata Berhad, Malaysia, and PT. XL Axiata, Indonesia. It can be said that the Axiata Group has very good programs and has been considered quite well. Where it can be seen from the several awards he has won such as Axiata Group which won the Sustainable Business Awards Malaysia 2018, Celcom Axiata which was named the Asia Responsible Enterprise Award in 2019 (Digital News Asia, 2019), and XL which was named The PR Indonesia Awards 2019 and Indonesia's Best Corporate Social Initiatives 2019.

Nevertheless, there are still several gaps for Axiata Group, Celcom, and XL to develop their CSR programs. Where it can be seen above that most of the programs that are owned are oriented towards education and capacity building as the main areas of CSR activities. Basically, by making education a priority in its CSR program, it can be said that PT. XL Axiata has thought about the output and outcome long-term of its program because it has been proven that investment in education can advance the peopless standard of living and help Indonesia achieve the title as a sovereign developed country, which has been proven by the assumptions and theories of Todaro (2011), as follows:

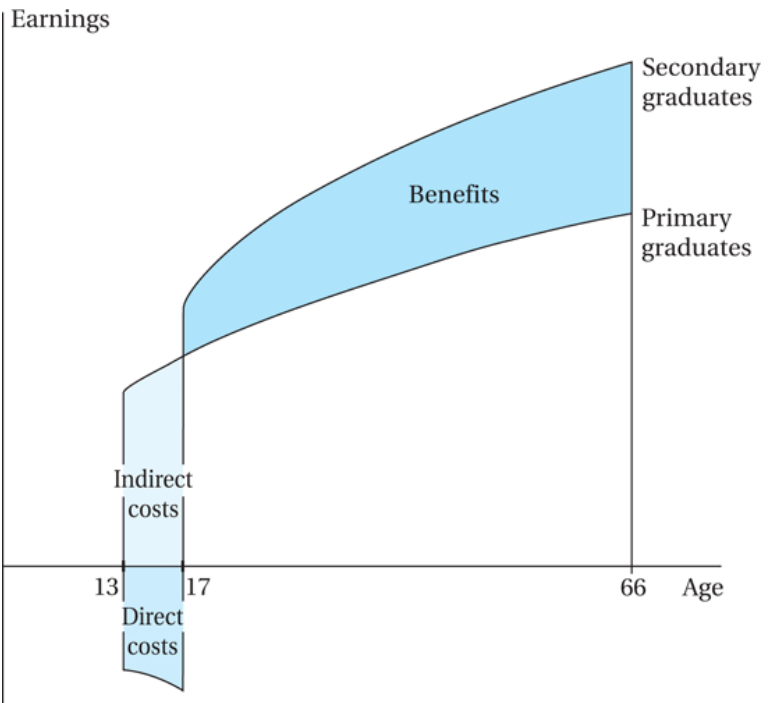

Direct costs

Figure 1. Assumptions and theories of Todaro

From the illustrations and theories above, it is explained that someone who prioritizes investing in human capital development, especially in the field of education, will later have a better income than those who do not invest. Although there are sacrifices or costs in the process, there are two kinds of costs in human development investment, namely direct and indirect costs (Todaro, 2011).

From the analysis that has been done by the company, it can be said that the company has programs that are included in six types of CSR programs. When viewed from the indicators of CSR success above, Axiata Group already has CSR that is quite successful. The program of the Axiata Group has had a considerable impact on the internal and external space of the company such as energy efficiency with solar incandescent, emission reduction, and others. from the external sphere also the company has had a huge social and economic impact.

However, when viewed from the perspective of human development or human resource development, the program carried out by the company only covers one of three aspects that can improve the standard of living and human development. The United Nations Development Program (UNDP) in Todaro (2011) explains, three important aspects are used as an index in human development, namely health as measured by life expectancy, knowledge or education as measured by literacy and education levels, and standard of living. as measured by per capita income juxtaposed with Purchasing Power Parity (PPP), these aspects are related to one another. 
Based on the human development theory described by Todaro (2011), there are three indicators, namely education, health, and economy. Referring to this theory, the Axiata Group's CSR program only adheres to two indicators. Namely education as the main area of CSR and several CSR activities. It aims to increase the economy, power purchase parity, or people's purchasing power. However, there are still no CSR activities that intersect with improving public health, especially during a pandemic (currently the Covid-19 pandemic is ongoing) like this, CSR in the health sector is what I feel is needed by the community.

Therefore, it can be said that investment in education and economy is not enough, this is because an individual cannot be productive if he only has higher education but does not have good health, and vice versa. So, it would be better if the company could create a health-based program, to increase Indonesia's life expectancy, such as creating insurance donation programs, vaccination, providing health facility assistance, building hospitals or health services, and others. If it is related to the field of the company, perhaps it can provide facilities for devices that can record public health data such as smart-bands or smart-watches that are intended to facilitate medical personnel. This is quite crucial because considering Indonesia>s hope figure is still at 69.4 years in 2017 (UNDP, 2018). The programs that have been implemented will later be evaluated by looking at the productivity of the Indonesian people and the increasing life expectancy of the Indonesian people.

\section{Conclusion}

In conclusion, CSR is a company relationship and commitment with stakeholders by integrating and considering social and environmental impacts, in the decision-making process and business activities. These activities are to improve the welfare of the surrounding communities and contribute to economic development. CSR is also a part of corporate responsibility, so it is carried out by business people regardless of any regulations regarding this matter.

From the analysis that has been carried out, the CSR activities that have been carried out by Axiata Group have fulfilled the six types of CSR and the company's CSR programs can be said to be successful with the indicators mentioned. When viewed from a perspective of human development, CSR is still only engaged in education and economics, but the health sector still does not have CSR initiatives from companies.

\section{REFERENCES}

Astri, H. (2012). Pemanfaatan Corporate Social Responsibility (CSR) Bagi Peningkatan Kualitas Hidup Manusia Indonesia. Aspirasi: Jurnal Masalah-Masalah Sosial, 3(2), 151-163. https://jurnal.dpr.go.id/index.php/aspirasi/ article/view/265

Budiarti, M., \& Raharjo, S. T. (2014). Corporate Social Responsibility (CSR) dari Sudut Pandang Perusahaan. Share : Social Work Journal, 4(1), 13-29. https://doi.org/10.24198/share. v4i1.13045

Crowther, D., \& Aras, G. (2008). Corporate Social Responsibility. Ventus Publishing ApS.

Handayani, M. T. (2020). Memahami pentingnya Corporate Social Responsibility. Ekrut.Com. https://www.ekrut.com/media/corporatesocial-responsibility-adalah

Harahap, A. S. (2010). Pengaturan Corporate Social Responsibility (CSR) di Indonesia. LexJurnalica, 7(3), 182-190. https://ejurnal.esaunggul. ac.id/index.php/Lex/article/view/313

Kurniasari, N. D. (2015). Program CSR Berbasis Pemberdayaan Masyarakat (untuk Meningkatkan Produktivitas Usaha Mikro, Kecil Menengah di Madura). Jurnal NeO-Bis, 9(1), 98-109. https://doi.org/10.21107/NBS. V9I1.685

Mondza, I. A. (2017). Peranan Corporate Social Responsibility (CSR) terhadap PT. Lafarge Cement Indonesia (LCI) Lhoknga, Aceh Besar [UniversitasSumateraUtara].http://repository. usu.ac.id/handle/123456789/68369

Solihin, I. (2009). Corporate Social Responsibility: From Chairity to Sustainibility. Penerbit Salemba Empat.

Sugiyono. (2008). Metode Penelitian Pendidikan: Pendekatan Kuantitatif, Kualitatif dan R\&D. Alfabeta.

Tanudjaja, B. B. (2006). Perkembangan Corporate Social Responsibility di Indonesia. NIRMANA, 8(2), 92-98. http://puslit2.petra. ac.id/ejournal/index.php/dkv/article / viewFile/17049/17013

Todaro, M. P. (2011). Pembangunan Ekonomi. Erlangga.

UNDP. (2018). Human Development Indices and Indicators. http://hdr.undp.org/sites/default/ files/2018_human_development_statistical_ update.pdf

Wardani, A. S. (2020). Bantu Tangani Covid-19, XL Donasi APD, Pulsa hingga Bagi Kuota Gratis. Liputan6.Com. https://www.liputan6.com/ tekno/read/4228725/bantu-tangani-covid19-xl-donasi-apd-pulsa-hingga-bagi-kuotagratis 
Wardiyanto, B. (2012). Administrasi Negara dan Corporate Social Responsibility: Sebuah Enabling Environment. Jejaring Administrasi Publik, 4(1), 73-79. http://journal.unair.ac.id/ download-fullpapers-admpdf1de1e257full.pdf
Wibisono, Y. (2007). Membedah Konsep dan Aplikasi CSR. Fascho Pub. 